DOI: $10.34185 / 1991-7848.2021 .01 .07$

УДК 629.7:658.512.2

П.Т. Мельянцов, О.М. Лосіков, В.С. Назарець, В.К. Сидоренко ${ }^{7}$

\title{
ПІДВИЩЕННЯ ПІСЛЯРЕМОНТНОЇ ДОВГОВІЧНОСТІ НАСОСІВ ПІДЖИВЛЕННЯ АКСІАЛЬНО-ПОРШНЕВИХ ГІДРОМАШИН
}

\begin{abstract}
Проводиться експериментальне підтвердження ефективності впровадження конструктивних заходів по зниженню об'ємних витрат в качаючому вузлі насоса підживлення через його торцевий зазор. Запропоновано конструкцію стенду та методику для обкатки і випробування насосів підживлення.
\end{abstract}

Ключові слова: насос підживлення, торцевий зазор, об'ємні витрати, коефіцієнт подачі, післяремонтна довговічність.

\section{Постановка проблеми}

Мобільні машини, що останнім часом широко застосовуються в гірничометалургійному комплексі, за конструктивними рішеннями оснащені гідравлічними трансмісіями. В значній мірі це обумовлюється конструктивними перевагами гідравлічних трансмісій в порівнянні 3 механічними, як з точки зору зручності керування мобільною машиною так і їі експлуатаційної надійності. Основними агрегатами гідравлічної трансмісії являються аксіально-поршневі гідромашини (аксіально-поршневий гідронасос НП-90 з регульованим об'ємом та не регульований аксіально-поршневий гідромотор МП-90).

Впровадження гідравлічних трансмісій в мобільних машинах передбачає їх високу експлуатаційну надійність в порівнянні з механічними трансмісіями, за рахунок особливості конструкції об’ємних гідромашин, качаючі вузли яких складаються 3 деталей, виготовлених 3 високою точністю геометричних розмірів. Разом 3 тим, проведений аналіз експлуатаційної надійності гідравлічних трансмісій мобільних машин показує, що на гідравлічний привід трансмісії припадає до 30\% відмов [1].

Проведений нами детальний аналіз відмов, показує, що основна їх частина (60-75\%) припадає на експлуатаційні відмови, які обумовлюються наступними причинами:

- експлуатація гідравлічних машин на робочих рідинах, які за класом чистоти не відповідають технічним вимогам (40-45\%);

- не своєчасна заміна робочих рідин та фільтруючих елементів, які передбачені регламентом планово-запобіжної системи 3 технічного обслуговування та ремонту (15-20\%);

(c) Мельянцов П.Т., Лосіков О.М., Назарець В.С., Сидоренко В.К., 2021 
- експлуатація гідравлічних трансмісій з низьким рівнем робочої рідини в гідравлічному баку гідросистеми (3-5\%);

- експлуатація гідравлічних машин на робочих рідинах з завищеним вмістом в них води (1-3\%);

- експлуатація гідравлічних трансмісій на робочих рідинах з завищеним вмістом повітря в робочій рідині в результаті порушення герметизації в гідравлічній системі (1-2\%).

$€$ очевидним, що вказані причини впливають на зміну структурних параметрів технічного стану деталей, які в свою чергу обумовлюють зростання об’ємних втрат робочої рідини та зменшення об'ємного коефіцієнту подачі аксіально-поршневого гідронасоса і втрату роботоздатності при досягненні його граничного значення.

Для забезпечення коефіцієнта подачі аксіально-поршневого гідронасоса, в відповідності до його технічної характеристики, на протязі тривалої експлуатації, в конструкції гідронасоса передбачається застосування насоса підживлення, головними функціями якого являється, компенсація об'ємних втрат в качаючому вузлі аксіально-поршневого гідронасоса та забезпечення роботи системи керування його робочим об'ємом.

Таким чином, можна припустити, що зміна структурних параметрів деталей насоса підживлення аксіально-поршневого гідронасоса буде також впливати на його роботоздатність i безпосередньо на експлуатаційну довговічність. Відновлення роботоздатності насосів підживлення, як правило проводиться в сервісних підприємствах, а післяремонтна довговічність буде обумовлюватись якістю ремонтних операцій технологічних процесів, які застосовуються на виробництві.

Детальний аналіз технологічних процесів показує, що запропонований в них метод відновлення роботоздатного стану насосів підживлення, основується на методі вільних ремонтних розмірів, який характеризується забезпеченням заданої форми робочої поверхні деталі, зняттям 3 її поверхні зношеного шару металу. $€$ очевидним, що його реалізація обумовлює зменшення коефіцієнта подачі та експлуатаційного ресурсу у відремонтованого насоса в порівнянні 3 новим, в результаті зміни геометричних розмірів деталей.

Усунення вище наведених недоліків можливе за рахунок впровадження передових методів відновлення роботоздатності насосів підживлення, реалізація яких забезпечить високу якість ремонту та експлуатаційну довговічність. 


\section{Аналіз останніх досліджень і публікацій}

Ресурсна відмова насоса підживлення аксіально-поршневого гідронасоса обумовлюється гідроабразивним зношенням робочих поверхонь деталей його качаючого вузла, що приводить до зростання зазорів в спряженнях і відповідно об’ємних втрат.

В роботах [2, 3], автори відмітили, що зміна структурних параметрів деталей в спряженнях «торець шестерні-верхня кришка» $\mathrm{i}$ «торець шестернінижня кришка» формує торцевий зазор, а в спряженні «колодязь корпусу-зуб шестерні» - радіальний зазор, що обумовлює зростання об'ємних втрат робочої рідини, а значить приводить до зменшення подачі насоса $(Q)$ л/хв і його об’ємного коефіцієнта корисної дії $\eta$.

Для компенсації торцевого зазору, в роботі [4], авторами запропоновано конструктивне рішення компенсації торцевого зазору, що включає в себе пластину з робочою поверхнею і пружнодемпфуючого елемента, у якому додатково розташовані канали й камери гідростатичного піджиму, при цьому, камери гідростатичного піджиму розміщені по колу через $90^{\circ}$ і з'єднані між собою каналами, отвори яких сполучені 3 камерою нагнітання. Водночас, в роботі рекомендується, для зменшення об'ємних втрат робочої рідини через торцевий зазор, забезпечити мінімальний зазор, який би формувався 3 врахуванням геометричного розміру абразивних частиць (50 мкм), кількість яких максимальна для десятого класу чистоти робочої рідини, на якій в відповідності до технічних вимог, експлуатуються насоси підживлення аксіально-поршневих гідромашин.

Дані конструктивні рішення представлені теоретично і не мають практичної реалізації, впровадження якої характеризується особливостями фізичного моделювання качаючого вузла насоса підживлення аксіальнопоршневого гідронасоса, конструктивними особливостями стенду для проведення лабораторних досліджень, методики виявлення функціональної залежності між ресурсом насоса і його об’ємним коефіцієнтом корисної дії.

\section{Мета дослідження}

Мета дослідження - підтвердження ефективності впровадження конструктивних заходів по зниженню об’ємних втрат в качаючому вузлі насоса підживлення через його торцевий зазор, в процесі ремонту, проведенням експериментальних досліджень.

\section{Викладення основного матеріалу дослідження}

Експлуатаційна довговічність насосів підживлення, що входять до складу регульованих аксіально-поршневих гідронасосів, в значній мірі обумовлюється 
технічним станом структурних параметрів деталей його качаючого вузла, які змінюються в результаті зношення деталей і обумовлюють зростання об'ємних втрат робочої рідини через торцевий зазор в качаючому вузлі насоса, що приводить до зменшення його об'ємного коефіцієнта подачі до граничних значень $\left(K_{Q} \leq 0,62\right)$ і ресурсної відмови [5].

Для відновлення роботоздатного стану насоса підживлення, на сервісних підприємствах застосовують метод вільних ремонтних розмірів, який характеризується видаленням слідів спрацювання на робочих поверхнях деталей торцевого зазору, з застосуванням операцій чорнового і чистового притирання робочих поверхонь верхньої та нижньої кришок насоса та торців зуба ведучої і веденої шестерень. Даний метод може бути реалізований для деталей 3 не значним зношенням, так як при значному зношенні суттєво змінюються геометричні розміри деталей після проведення притирочних операцій, що обумовлює зменшення об’ємного коефіцієнта його подачі i відповідно післяремонтного ресурсу.

Одним із ефективних заходів, який дозволяє збільшити післяремонтну довговічність насоса підживлення, при поступанні до ремонту, являється застосування в качаючих вузлах механізму компенсації торцевого зазору [4].

Для його реалізації автори рекомендують, при проведенні ремонтних робіт, установити в верхній кришці насоса пластину для компенсації торцевого зазору, яка складається з робочої поверхні і пружнодемпфуючого елемента, у якому додатково розташовані канали й камери гідростатичного піджиму, при цьому камери гідростатичного піджиму розміщені по колу через 90 і з’єднані між собою каналами, отвори яких сполучені з камерою нагнітання (рисунок 1).

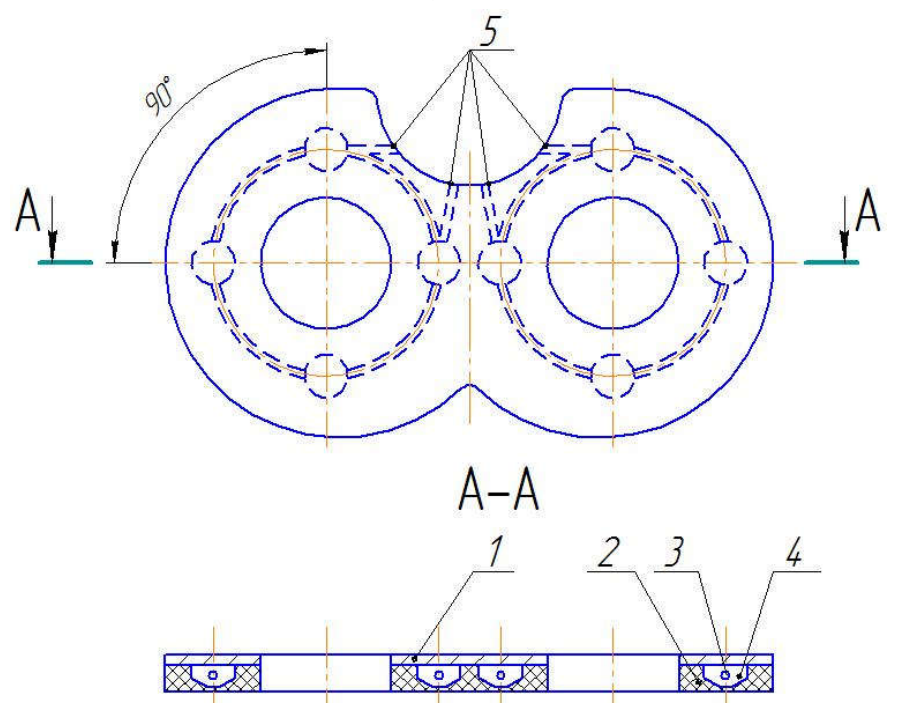

Рисунок 1 - Конструкція пластини компенсації торцевого зазору: 1 - робоча поверхня;

2 - опорна поверхня; 3 - пружньодемпфуючий елемент; 4 - камери піджиму;

5 - канали для подачі рідини 
Для підтвердження ефективності даного способу ремонту насоса підживлення, з точки зору збільшення його післяремонтної довговічності, в порівнянні з застосуванням існуючої технології ремонту насоса, яка базується на застосуванні вільних ремонтних розмірів і характеризується видаленням слідів зношення на робочих поверхнях деталей, які формують торцевий зазор («торець шестерень-верхня кришка насоса», «торець шестерень-нижня кришка насоса») проводяться лабораторні дослідження.

у відновлених насосів запропонованими способами визначалась функціональна залежність між об'ємним коефіцієнтом подачі насоса $\left(K_{Q}\right)$ і його наробітком в перші 50...60 годин його роботи, які характеризуються інтенсивністю зношення робочих поверхонь деталей, що формують торцевий зазор, в результаті їх припрацювання і впливають на післяремонтний ресурс насоса в умовах експлуатації.

Об'ємний коефіцієнт подачі насоса $\left(K_{Q}\right)$ визначався з застосовуванням виразу [6]:

$$
K_{Q}=\frac{Q_{\phi}}{Q_{m}},
$$

де $Q_{\phi}$ - фактична подача насоса при номінальних тиску і частоті обертання вала, $c м^{3} /$ об; $Q_{m}$ - теоретична (розрахункова) подача насоса при номінальній частоті обертання валу насоса, $\mathrm{cm}^{3} /$ об .

Для виконання лабораторних досліджень була проведена модернізація стенда КИ-4815М, гідравлічна схема якого наводиться на рисунок 2 [5].

Модернізована конструкція стенду має розширені функціональні можливості для випробовування гідравлічних насосів в порівнянні з існуючими марками стендів (КИ-4815М, КИ-4200), до яких можна віднести безступеневе регулювання швидкості ведучої шестерні насоса за допомогою застосування гідравлічного приводу ведучого валу насоса, який також забезпечує випробування насосів з лівим і правим напрямом обертання ведучої шестерні та створювати стато-динамічний режим роботи насоса за швидкісним режимом.

Випробовування насосів проводились на маслі для гідравлічних приводів МГЕ-46В (ТУ 38.10150-70), при температурі $50 \pm 5^{0} \mathrm{C}$ на робочих швидкостях приводного валу в інтервалі $\left(n=700 \ldots 1450 x e^{-1}\right)$, а їх технічний стан визначався по фактичній подачі за допомогою гідравлічного лічильника ШЖУ-25М-16 (ДСТУ 12671-01), при номінальному тиску робочої рідини в нагнітаючій магістралі $\left(P_{H}=1,44 \pm 0,01 M П а\right)$ і частоті обертання ведучого валу $n=1450 x 8^{-1}$. 


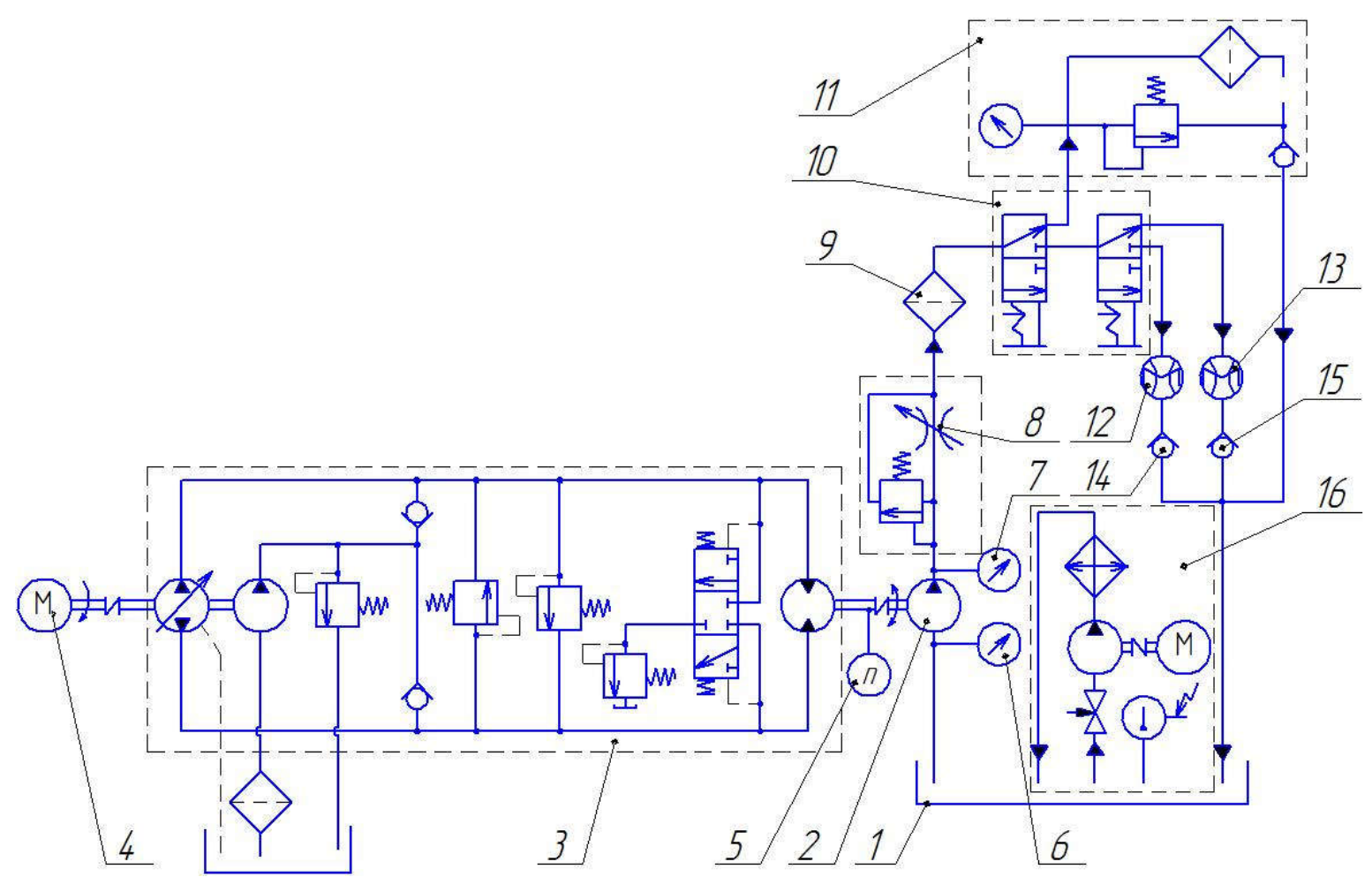

Рисунок 2 - Гідравлічна схема стенда для обкатки та випробовування насосів підживлення аксіально-поршневої гідромашини [5]:1 - гідравлічний бак;

2 - насос, що випробовується; 3 - гідравлічний привод ведучого валу насоса;

4 - електродвигун; 5 - лічильник обертів; 6 - вакуумметр; 7 - манометр;

8 - регульований дросель; 9 - фільтр тонкої очистки; 10 - розподільний блок;

11 - блок очищення робочої рідини; 12, 13 - лічильниками рідини;

14, 15 - зворотні клапани; 16 - блок охолодження

При проведенні експериментальних робіт на стенді витримуються слідуючи загальні умови: рівень робочої рідини стенду періодично контролюється, a iï забруднення не допускається; після проведення на стенді демонтажних робіт, що включають в себе роз'єднання трубопроводів, із системи видаляється повітря; підключення до стенду додаткових пристроїв, необхідних для проведення експерименту, не повинно змінювати гідравлічний опір та об'єм нагнітаючої магістралі, а також впливати на тиск в зливній магістралі.

Фактична подача насосів визначалась через кожні десять годин їх випробовування, при номінальних значення тиску рідини в нагнітаючій магістралі $\left(P_{H}=1,44 \pm 0,01 M П а\right)$ і частоті обертання ведучого валу $n=1450 x \varepsilon^{-1}$. В проміжках часу, коли подача насоса не контролювалась, моделювались умови його роботи, які максимально відтворювали режим роботи в умовах експлуатації таблиці 1. 
Таблиця 1

Режим роботи насоса на експериментальному стенді прогом інтервалу десять годин

\begin{tabular}{|l|l|l|l|}
\hline $\begin{array}{l}\text { Тривалість } \\
\text { випробовування } \\
\text { насоса в год. }\end{array}$ & $\begin{array}{l}\text { Тиск } \\
\text { нагнітаючій } \\
\text { магістралі } \\
\text { насоса, МПа }\end{array}$ & $\begin{array}{l}\text { Температура } \\
\text { робочої рідини, }{ }^{0} C\end{array}$ & $\begin{array}{l}\text { Частота обертання } \\
\text { приводного } \\
\text { валу стенда, } x 8^{-1}\end{array}$ \\
\hline 1,0 & $0,22 \pm 0,01$ & $50 \pm 5$ & 700 \\
\hline 2,0 & $0,36 \pm 0,01$ & $50 \pm 5$ & 783 \\
\hline 3,0 & $0,50 \pm 0,01$ & $50 \pm 5$ & 866 \\
\hline 4,0 & $0,64 \pm 0,01$ & $50 \pm 5$ & 949 \\
\hline 5,0 & $0,76 \pm 0,01$ & $50 \pm 5$ & 1032 \\
\hline 6,0 & $0,90 \pm 0,01$ & $50 \pm 5$ & 1075 \\
\hline 7,0 & $1,04 \pm 0,01$ & $50 \pm 5$ & 1115 \\
\hline 8,0 & $1,18 \pm 0,01$ & $50 \pm 5$ & 1198 \\
\hline 9,0 & $1,32 \pm 0,01$ & $50 \pm 5$ & 1250 \\
\hline 10,0 & $1,44 \pm 0,01$ & $50 \pm 5$ & 1450 \\
\hline
\end{tabular}

Експлуатація насоса на даних режимах підвищувала достовірність результатів експериментальних досліджень 3 виявлення функціональної залежності між коефіцієнтом подачі насоса і часу напрацювання.

Результати стендових досліджень випробування насосів підживлення від часу напрацювання наведено в (таблицях 2,3 ) i наглядно представлені в рисунку 3.

Таблиця 2

Результати експериментальних досліджень зміни коефіцієнта подачі насоса підживлення з механізмом компенсації торцевого зазору від часу напрацювання

\begin{tabular}{|l|lr|l|l|l|}
\hline $\begin{array}{l}\text { Час } \\
\text { обкатки } \\
\text { насоса, } \\
\text { год. }\end{array}$ & $\begin{array}{l}\text { Теоретична } \\
\text { насоса } \\
\text { номінальній } \\
\text { обертання } \\
\text { см }^{3} / \text { об }\end{array}$ & $\begin{array}{r}\text { пасточа } \\
\text { валу, }\end{array}$ & $\begin{array}{l}\text { Номінальний } \\
\text { тиск, МПа }\end{array}$ & $\begin{array}{l}\text { Дійсна подача насоса } \\
\text { при номінальній } \\
\text { частоті обертання } \\
\text { валу, см }{ }^{3} / \text { об }\end{array}$ & $\begin{array}{l}\text { Коефіцієнт } \\
\text { об'єної } \\
\text { подачі } \\
\text { насоса, } K_{Q}\end{array}$ \\
\hline 10 & 19,50 & $1,44 \pm 0,01$ & 17,47 & 0,896 \\
\hline 20 & 19,50 & $1,44 \pm 0,01$ & 17,41 & 0,893 \\
\hline 30 & 19,50 & $1,44 \pm 0,01$ & 17,36 & 0,890 \\
\hline 40 & 19,50 & $1,44 \pm 0,01$ & 17,34 & 0,889 \\
\hline 50 & 19,50 & $1,44 \pm 0,01$ & 17,32 & 0,888 \\
\hline 60 & 19,50 & $1,44 \pm 0,01$ & 17,30 & \\
\hline
\end{tabular}


Таблиця 3

Результати експериментальних досліджень зміни коефіцієнта подачі насоса підживлення відновленого за типовою технологією від часу напрацювання

\begin{tabular}{|c|c|c|c|c|}
\hline $\begin{array}{l}\text { Час } \\
\text { обкатки } \\
\text { насоса, } \\
\text { год. }\end{array}$ & $\begin{array}{lr}\text { Теоретична } & \text { подача } \\
\text { насоса } & \text { при } \\
\text { номінальній } & \text { частоті } \\
\text { обертання } & \text { валу, } \\
\text { cм }^{3} / \text { об } & \end{array}$ & $\begin{array}{l}\text { Номінальний } \\
\text { тиск, МПа }\end{array}$ & $\begin{array}{lr}\text { Дійсна подача насоса } \\
\text { при } & \text { номінальній } \\
\text { частоті } & \text { обертання } \\
\text { валу, } \mathrm{cm}^{3} & \text { / об }\end{array}$ & $\begin{array}{l}\text { Коефіцієнт } \\
\text { об’ємної } \\
\text { подачі } \\
\text { насоса, } K_{Q}\end{array}$ \\
\hline 10 & 19,50 & $1,44 \pm 0,01$ & 17,12 & 0,878 \\
\hline 20 & 19,50 & $1,44 \pm 0,01$ & 17,04 & 0,874 \\
\hline 30 & 19,50 & $1,44 \pm 0,01$ & 16,91 & 0,867 \\
\hline 40 & 19,50 & $1,44 \pm 0,01$ & 16,83 & 0,863 \\
\hline 50 & 19,50 & $1,44 \pm 0,01$ & 16,75 & 0,859 \\
\hline 60 & 19,50 & $1,44 \pm 0,01$ & 16,63 & 0,853 \\
\hline
\end{tabular}

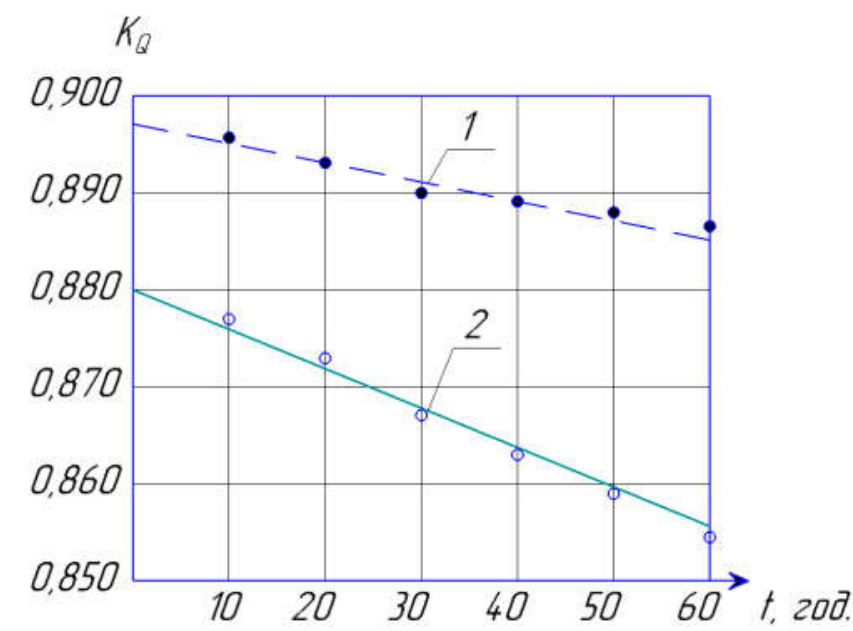

Рисунок 3 - Залежність коефіцієнта подачі $\left(K_{Q}\right)$ насоса підживлення від наробітку $(t)$ :

1 - насос підживлення відремонтовано з застосуванням механізму компенсації торцевого зазору; 2 - насос підживлення відремонтовано за типовою технологією

Проведений аналіз отриманих результатів, наведених в (табл.2, табл.3) показує, що після наробітку десять годин коефіцієнт подачі насоса, у якого в качаючому вузлі встановлено механізм компенсації торцевого зазору, становить $K_{Q}=0,896$, що практично прирівнюється до нового насосу $\left(K_{Q}=0,90 \ldots 0,92\right)$, тоді як у насоса, відремонтованого за типовою технологією, коефіцієнт подачі становить $K_{Q}=0,878$.

Поява такої різниці в показниках коефіцієнта подачі на начальних етапах експлуатації насосів вказує на те, що запропонована технологія ремонту 3 застосуванням механізму компенсації торцевого зазору, забезпечує мінімальне значення торцевого зазору в спряженні «поверхня притискної пластини - 
торець шестерні», який формується співвідношенням сили притискання пластини до торцевої частини шестерні, i сил відтискання, які будуть відтискати пластину від торцевої поверхні шестерень за рахунок сили несучої здатності масляної плівки робочої рідини в торцевому зазорі.

Відносна зміна коефіцієнта подачі для насоса, з механізмом компенсації торцевого зазору, від початку випробувань його на стенді і до їх завершення становить $1,0 \%$, що вказує на стабільну роботу механізму компенсації торцевого зазору в качаючому вузлі насоса.

Водночас, у насоса підживлення, відновленого за типовою технологією, значення торцевого зазору має величину, яка обумовлюється величиною геометричних розмірів деталей, що сформувались після їх притирання в процесі ремонту. $€$ очевидним, що в процесі подальшої експлуатації даного насоса, розмір торцевого зазору буде збільшуватись в результаті зношення деталей, що підтверджується значенням коефіцієнта подачі, який становить $K_{Q}=0,853$ за 60 год. обкатки насоса на експериментальному стенді.

Відносна зміна коефіцієнта подачі для даного насоса від початку випробувань його на стенді і до їх завершення становить 2,9\%, що вказує на інтенсивність зміни торцевого зазору в результаті припрацювання деталей в спряженнях на початку роботи насоса і відповідно зменшення ресурсу насоса в період його експлуатації.

Детальний аналіз отриманих графіків показує, що на момент завершення стендових випробувань коефіцієнт подачі насоса, відремонтованого, 3 застосуванням механізму компенсації торцевого зазору, на 4\% більший, в порівнянні 3 коефіцієнтом подачі насоса відремонтованого за типовою технологією.

Являється явним, що забезпечення відносно високого показника коефіцієнта подачі насоса підживлення, відновленого 3 застосуванням механізму компенсації торцевого зазору, в період його обкатки та випробовування забезпечить $\gamma$-ресурс (80\% від ресурсу нового насоса) для відремонтованого насоса в умовах експлуатації.

\section{Висновки}

1. Проведений детальний аналіз відмов аксіально-поршневих гідромашин, показав, що основна їх частина (60-75\%) припадає на експлуатаційні відмови, які в основному обумовлюються технічним станом робочої рідини, що приводить до гідроабразивного зношення робочих поверхонь деталей качаючого вузла насоса підживлення аксіально-поршневого гідронасоса, зростання зазорів в спряженнях і відповідно об’ємних втрат. 
2. Для забезпечення післяремонтної довговічності насосів підживлення при відновленні їх роботоздатності, рекомендується застосування в їх качаючих вузлах механізму компенсації торцевого зазору, який представляє собою пластину, що складається з робочої поверхні і пружнодемпфуючого елемента, у якому додатково розташовані канали й камери гідростатичного піджиму.

3. Розроблена конструкція стенду для обкатки та випробовування насосів підживлення, яка забезпечує безступеневе регулювання швидкості ведучої шестерні насоса за допомогою застосування гідравлічного приводу ведучого валу, випробування насосів з лівим і правим напрямом обертання ведучої шестерні, та створює стато-динамічний режим роботи насоса за швидкісним режимом.

4. Відносна зміна коефіцієнта подачі для насоса, 3 механізмом компенсації торцевого зазору, від початку випробувань його на стенді і до їх завершення становить $1,0 \%$, що вказує на стабільну роботу механізму компенсації торцевого зазору в качаючому вузлі насоса i ефективність запропонованих рішень 3 точки зору збільшення його післяремонтної довговічності.

5. Відносна зміна коефіцієнта подачі для насоса підживлення, відновленого за типовою технологією, від початку випробувань його на стенді і до їх завершення становить $2,9 \%$, що вказує на інтенсивність зміни торцевого зазору в результаті припрацювання деталей в спряженнях на початку роботи насоса і відповідно зменшення ресурсу насоса в період його експлуатації.

6. На момент завершення стендових випробувань коефіцієнт подачі насоса, відремонтованого, з застосуванням механізму компенсації торцевого зазору, на 4\% більший, в порівнянні 3 коефіцієнтом подачі насоса відремонтованого за типовою технологією, що збільшує ймовірність забезпечення $\gamma$-ресурсу (80\% від ресурсу нового насоса) для відремонтованого насоса в умовах експлуатації.

\section{ЛІТЕРАТУРА}

1. Мельянцов П. Т. Опыт ремонта гидропривода ГСТ-90 на ремонтных предприятиях [Текст] / П. Т. Мельянцов, Б. Г. Харченко, И. Г. Голубев. - М.: АгроНИИТЭИИТО, 1989. - 42 с.

2. Лосіков О. М. «Вид та характер зношення деталей качаючого вузла насоса підживлення аксіально-поршневої гідромашини». Металлургическая и горнорудная промышленность. 2015.-№7.-C.170-173

3. Мельянцов П. Т., Лосіков О. М. «Вплив торцевого зазору качаючого вузла насоса підживлення гідроприводу трансмісії ГСТ-90 на сумарні об'ємні втрати». Металлургическая и горнорудная промышленность. -2015.-№7.-С.174-177.

4. Мельянцов П. Т., Лосіков О. М., Мовчан В. Ф. Конструктивні рішення по зниженню об’ємних втрат робочої рідини в шестеренних насосах підживлення аксіально-поршневих гідромашин. Сучасні проблеми металургії. Наукові вісті. 2019 № 22. С. 52-61. 
5. Стенд для обкатки та контролю технічного стану насоса підживлення аксіально-поршневої гідромашини / Мельянцов П. Т., Лосіков О. М.: пат. 98408 Україна: МПК (2015.1) F15B 19/00. № u201412365; заявл. 17.11.2014; опубл. 27.04.2015, Бюл. № 8 .

6. Юдин Е. М. Шестеренные насосы. - М.: Машиностроение, 1964.- 235 с.

\section{REFERENCES}

1. Melyantsov P.T. Experience of repair of the GST-90 hydraulic drive at repair enterprises [Text] / P.T. Melyantsov, B.G. Kharchenko, I.G. Golubev. - M .: AgroNIITEIITO, 1989. - 42 p.

2. Losikov O.M. "Type and nature of wear of parts of the oscillating unit of the booster pump of axialpiston hydraulic feed pumps". Metallurgical and mining industries. - 2015.-№7.-p.170-173.

3. Melyantsov P.T., Losikov O.M. "The influence of the end clearance of the oscillating unit of the booster pump of transmission hydraulic drive GST-90 on total volume losses." Metallurgical and mining industries. - 2015.-№7.-p.174-177.

4. Melyantsov P.T., Losikov O.M., Movchan V.F. Design solution for reduction of volume losses of hydraulic fluid in the gear booster pumps of axial-piston hydraulic feed pumps. Current problems in metallurgy. Science news. 2019 No. 22. p. 52-61.

5. The stand for running-in and technical condition control of booster pump of axial-piston hydraulic feed pumps / Melyantsov P.T., Losikov O.M.: pat. 98408 Ukraine: IPC (2015.1) F15B 19/00. № u201412365; declared 17.11.2014; publ. 27.04.2015, Bull. № 8 .

6. Yudin E.M. Gear pumps. - M .: Mashinostroenie, 1964.- 235 p.

Received 09.02.2021. Accepted 15.02.2021.

UDC 629.7:658.512.2

P. Melyantsov, O. Losikov, V. Nazarets, V. Sidorenko

\section{THE INCREASING OF POST-REPAIR DURABILITY OF AXIAL-PISTON HYDRAULIC FEED PUMPS}

The influence of constructive decisions on compensation of an end gap in the pumping unit of the pump of feeding of the axial-piston hydraulic pump, at restoration of its working condition, on its post-repair durability is considered.

The influence of the end gap in the couplings of the pumping unit of the feed pump on the volumetric losses of the working fluid and on the volumetric coefficient of its supply is investigated. A method of conducting experimental and laboratory studies to identify the functional relationship between the supply coefficient of the pump and its operating time.

The proposed design of the stand for experimental research on running-in and testing of feed pumps, which provides stepless speed control of the pump drive gear using a hydraulic drive shaft, testing pumps with left and right direction of rotation of the drive gear, and creates a static dynamic mode speed mode, which ensures the efficiency of the running-in mode of the parts in the couplings of the pumping unit of the feed pump.

The developed design of the stand for running-in and testing of feed pumps can be realized at the enterprises on technical service of hydraulic units.

A detailed analysis of failures of axial-piston hydraulic machines, which showed that most of them (60-75\%) are operational failures, which are mainly due to the technical condition of the working fluid, which leads to hydroabrasive wear of the working surfaces of the pumping unit of the axial feed pump piston hydraulic pump, increasing gaps in the couplings and, accordingly, volume losses. 
The relative change of the supply factor for the pump is determined, with the mechanism of compensation of the end gap, which indicates the stable operation of the compensation mechanism and the efficiency of the proposed solutions in terms of increasing its post-repair durability.

It is shown that the change in the supply factor of the pump, restored by standard technology, is due to the intensity of the change of its end gap as a result of running in the couplings at the beginning of the pump and accordingly to reduce the pump life during its operation.

From the comparative assessment of the supply coefficients of pumps repaired using the end clearance compensation mechanism and the typical technology, it follows that the proposed technology is more likely to provide $80 \%$ of the resource in service conditions for the repaired pump.

Key words: booster pump, end clearance, volume losses, charge efficiency, post-repair durability.

Мельянцов Петро Тимофійович - к.т.н., доцент, кафедра надійності і ремонту машин, Дніпровський державний аграрно-економічний університет.

Лосіков Олександр Михайлович - старший викладач, кафедра колісних та гусеничних транспортних засобів, Національна металургійна академія України.

Назарець Віктор Семенович - к.т.н., доцент, кафедра колісних та гусеничних транспортних засобів, Національна металургійна академія України.

Сидоренко Віктор Кононович - старший викладач, кафедра колісних та гусеничних транспортних засобів, Національна металургійна академія України.

Мельянцов Петр Тимофеевич - к.т.н., доцент, кафедра надежности и ремонта машин, Днепровский государственный аграрно-экономический университет.

Лосиков Александр Михайлович - старший преподаватель, кафедра колесных и гусеничных транспортных средств, Национальная металлургическая академия Украины.

Назарец Виктор Семенович - к.т.н., доцент, кафедра колесных и гусеничных транспортных средств, Национальная металлургическая академия Украины.

Сидоренко Виктор Кононович - старший преподаватель, кафедра колесных и гусеничных транспортных средств, Национальная металлургическая академия Украины.

Melyantsov Petr - Ph.D., associate professor, department of reliability and repair of machines, Dnipro State Agrarian-Economic University.

Losikov Olexander - senior lecturer, department of wheeled and full-track vehicles, The National Metallurgical Academy of Ukraine.

Nazarets Viktor - Ph.D., associate professor, department of wheeled and full-track vehicles, The National Metallurgical Academy of Ukraine.

Sidorenko Viktor - senior lecturer, department of wheeled and full-track vehicles, The National Metallurgical Academy of Ukraine. 